\title{
Vinaya monasteries in the eyes of early Qing emperors
}

\author{
Lidia Vetluzhskaya ${ }^{1}$, and Mariia Lepneva, ${ }^{2, *}$ \\ ${ }^{1}$ Banzarov Buryat State University, Department of Philology of Countries of the Far East, 670000, Smolina st. 24a, Ulan-Ude, Russia \\ ${ }^{2}$ Banzarov Buryat State University, Department of History and Regional Studies of Asian Countries, 670000, Smolina st. 24a, Ulan-Ude, \\ Russia
}

\begin{abstract}
By the first half of the eighteenth century, lineages of the Buddhist Vinaya school (Lüzong) took hold in several monasteries in Beijing. However, when the Yongzheng emperor designed a grand ordination ceremony to be held in 1734 he opted to summon a Vinaya patriarch from a distant Mt Baohua near Nanjing. This article aims to provide an explanation for such a choice by means of exploring the image of relevant Vinaya monasteries in the eyes of early Qing emperors, relying mainly on the evidence in the gazetteers of these monasteries. Our findings show that Vinaya monasteries in Beijing, such as Tanzhe, Guangji, and Minzhong, enjoyed considerable imperial patronage. At the same time, only Minzhong monastery was perceived as a purely Vinaya site, while the image of its counterparts was rather heterogeneous. The main advantage that could have singled out the abbot of Mt Baohua Fuju (1686-1765) was the first full-fledged school genealogy that he compiled in 1733, while other monasteries in question did not possess an identity of sites with strong and stable Vinaya lineages at that time. Accordingly, Yongzheng might have wished to promote a genealogically organized Vinaya school as a check-andbalance against swelling Chan lineages.
\end{abstract}

\section{Introduction}

Yongzheng 雍正 (1678-1735, r. 1722-1735), the third emperor of the Qing dynasty in China, is distinguished by deep involvement with Buddhism. He formed close ties with Chan monks and interfered in disputes between Chan lineages, initiated a new edition of the Chinese Buddhist canon and restored a number of monasteries [1; 2 , p. 175-182; 3; 4]. During the later years of his life, he engaged with yet another school of Buddhism - Vinaya (Lüzong 律宗) that dealt primarily with disciplinary matters. The emperor summoned Vinaya monk Wenhai Fuju 文海福聚 (1686-1765, hereafter "Fuju”) from Mt Baohua 寶華山 (located near Nanjing) to Beijing to conduct an ordination ceremony for fifteen hundred aspiring novices.

The scholarship has already paid attention to this event, mainly referring to the emperor's decrees that document the proceedings of Fuju's stay in the capital [5, p. 472, 495]. By contrast, a distinguished scholar of Ming-Qing Buddhism Hasebe Yūkei inquired about Yongzheng's reasons for arranging such ceremony. The Japanese researcher suggested that the emperor could have tried to uphold Vinaya in order to suppress the swelling Chan community [6, p. 91-92]. In particular, conducting an ordination ceremony under the supervision of a Vinaya master should have stressed the necessity to revive the custom of transmitting monastic precepts only by a Vinaya expert. Hasebe Yūkei proceeded to observe another problem pertaining to
Yongzheng's choice. The emperor preferred to invite a monk from a distant region despite the fact that other Vinaya monasteries existed in Beijing at that time. The Japanese scholar explains this by supposition that Yongzheng must have considered those Beijing monasteries to be "inferior" (J. kafū 下風) to their southern counterpart, but falls short of providing evidence of such inferiority. This paper constitutes an attempt to further clarify what knowledge could have informed Yongzheng's decision, considering the degree of awareness and perception of Vinaya monasteries by Yongzheng as well as his predecessors. Without challenging the overall proposition about Yongzheng's desire to uphold Vinaya lineage to suppress Chan ${ }^{\mathrm{a}}$, this research probes why exactly Yongzheng arrived at the decision to summon Fuju at the cost of Beijing clergy.

\section{Vinaya lineages during Late Ming and Early Qing}

As the Jiajing emperor 嘉靖 (1507-1567, r. 1521-1567) banned ordination ceremonies and the Wanli emperor 萬 曆 (1563-1620, r. 1572-1620) was reluctant to lift the ban, the Vinaya reviver Guxin Ruxin 古心如馨 (15411616, hereafter "Ruxin") stood out prominently as the

\footnotetext{
${ }^{a}$ It is further supported by the fact that the aforementioned moves against the wrongdoings of Chan were undertaken by Yongzheng in 1733-134 that is exactly the same time when he engaged with the Vinaya school.
}

Corresponding author: marystoryteller@mail.ru 
monk who managed to gain approval for resuming ordinations. Among about a dozen main disciples of Ruxin, four gave rise to new Vinaya lineages, i.e. Gulin 古林, Minzhong 慰忠, Shengguang 聖光, and Qianhua 千華. The proliferation of these lineages to monasteries in various parts of China is described by Hasebe Yūkei and Shi Shengkai [7-8]. More specifically, the Japanese scholar points out that Vinaya lineages were present in such famous monasteries in the capital as Minzhong 慰 忠寺 (“Pity for the Loyal Ones”), Tanzhe 潭柘寺 (“Pool and Mulberry"), Guangji 廣濟寺 (“Vast Relief”), and besides that in lesser-known Ruiying 瑞應 寺 (“Auspicious Resonance”), Heita 黑塔寺 ("Black Pagoda") and Jile 極樂寺 ("Extreme Happiness") [6, p. 94]. This list is obviously based on Fuju's genealogical text Genealogy of Nanshan School [9], which was the main subject of the relevant article by the Japanese scholar. Yet, it should be noted that the material of the genealogy primarily reflects the understanding within the Vinaya community rather that the outlook of the emperors. Therefore, it is appropriate to ask whether these or any other Vinaya monasteries of the time fell within the imperial eyesight, and if they did, whether they were actually perceived by the emperors as highly esteemed Vinaya sites.

\section{Vinaya Monasteries in Beijing and on Mt Baohua}

Even though Hasebe Yūkei named six monasteries in Beijing as centres of Vinaya school, they were not uniform with regard to their prominence. Heita and Jile monasteries are weakly represented in available sources, while Ruiying monastery fell out of favour as its main patron opposed Yongzheng's ascending to the throne. Therefore this research will focus on the remaining three Beijing monasteries as well as on Mt Baohua.

\subsection{Minzhong monastery}

Minzhong monastery, located off the Xuanwu Gate 玄武 門, was restored in 1437 by the Zhengtong emperor 正統 (1427-1464, reigned first as Zhengtong in 1435-1449, and then as Tianshun 天順 in 1457-1464). It underwent more restorations during the Ming in 1445, 1601, 16341635. The aforementioned Minzhong lineage originated from this monastery, as Ruxin's disciple Dahui Yonghai 大會永海 (d. 1628/9) became abbot during the Wanli reign [10, p. 0713a14-16]. The Shunzhi 順治 (16381661, r. 1644-1661) reign saw the construction of an ordination platform, while Kangxi 康熙 (1654-1722, r. 1661-1722) granted a plaque for the ordination platform “Juelu jinliang” 覺路津梁 ("Ferry and bridge on the path to awakening") [11; 4, p. 179]. Moreover, on January 31, 1661, the Shunzhi emperor visited the monastery to watch the tonsure of a eunuch Wu Liangyong 吴良庸 [12, p. 43, 45]. This happened on the eve of the emperor's death from smallpox on February 5. Thus, Minzhong monastery was virtually his last resort amid fateful calamity. This tells much of the esteem in which Shunzhi held the temple.

The fifth abbot Purun Changxiu 普潤常修 (d. 1672) was chosen by the Qing court for conducting an ordination ceremony. After the outbreak of Revolt of the Three Feudatories (1673-1681) the Kangxi emperor visited the monastery, and the sixth abbot Shizong Shouxi 釋惚授雪 (d. 1690) predicted the defeat of the rebels. After the appeasement of the rebellion, Kangxi returned to the monastery and remembering the prophecy wrote two characters “Cuncheng”存誠 ("Preserving sincerity"), which the abbot made into a plaque. After this, Shizong Shouxi entered the palace and saw the emperor many times. Kangxi also granted him a precious pearl [12, p. 88-89].

After the Revolt of the Three Feudatories, the next abbot Yangyue Haichao 仰月海潮 (d. 1694) raised funds and held "sanctuary for the deliverance of creatures of land and water" (shuilu daochang 水陸道場) to relieve the spirits of the dead. Upon hearing about this, Kangxi ordered painter Yang Zhimao 楊之茂 to make 120 paintings of water, land, spirits, sages, objects, monsters, people, and demons to be preserved in the monastery in order to support the good karmic connection. The eighth abbot Xinzong 心宗 (d.u.) built a library to house the Buddhist canon granted by the emperor, and Kangxi personally wrote a plaque for it. The tenth abbot Hongxiu 洪修 was often visited by Kangxi as an expert and eventually received a purple robe from him. However, Hongxiu was more interested in Chan practice and eventually built another monastery for himself named Dinghui 定慧, which received from Kangxi a title "foundating abbot of Dinghui monastery" (Dighuisi kaishan zhuchi 定慧寺開山住持). The eleventh abbot Xingshi Tide 行實體德 (d. 1726), who studied from Hongxiu and received his transmission, also was granted a purple robe by Kangxi and widely socialized with literati. Little is known about the relations of the twelfth and thirteenth abbots Shili 師禮 (d.u.) and Huikuan Xing 慧寬性 (d.u.) with the emperor, except for the fact that when in 1734 the Yongzheng emperor summoned Fuju from Mt Baohua and completed the restoration of Minzhong monastery, Huikuan Xing left with his disciples for the tenth abbot's retirement place - Dinghui monastery [12, p. 90-94].

\subsection{Guangji monastery}

Hongci Guangji monastery 弘慈廣濟寺, located in Xicheng Disctrict 西城區 of Beijing, was revived through the efforts of monk Xiyun Puhui 喜雲普慧 (d. 1470/71) and his scholar-official patrons during the early Tianshun reign period of the Ming upon which the monastery. At this time the site, previously known as Xiliucun monastery 西劉村寺, received its present name [13, p. 96]. The period of Ming-Qing transition saw the appearance of outstanding monks here: Hengmin Xingmei 恒明性美 (d. 1667) was renowned for his austere practices, while Manyue Qing 滿月清 (d. 
1645/6) was well versed in the doctrine and lectured relentlessly. Grieving the lack of discipline amid the clergy, Hengshi Xingmei suggested in 1648 that Vinaya master Yuguang Kuanshou 玉光寬壽 (1582-1661), who had just returned from pilgrimage to Mt Wutai 五台山, should be made the abbot. Yuguang Kuanshou received precepts from Dahui Yonghai, the aforementioned first Vinaya abbot of Minzhong monastery, and thus belonged to the Minzhong lineage of the Vinaya school [10, p. 0721a12]. As the monastery gazetteer clearly states, it was at this point that "Guangji became a Vinaya monastery within the capital" [13, p. 106, 119]. Yuguang Kuanshou is said to have attained significant spiritual achievements through his diligent meditation practice. At the same time, he intensively propagated precepts: he conducted ordinations in strict manner for thirteen years, three times a year, with thousands of precept disciples $[13$, p. 120].

It was at the time of this master that Guangji monastery finally attracted imperial attention. The fame of Yuguang Kuanshou reached the imperial palace, and the Shunzhi emperor visited Guangji monastery in the winter of 1657. The following interaction was dramatic, as Yuguang Kuanshou refused to bow to the emperor and to come when summoned referring to the teachings of the Brahma Net Sutra. Yuguang Kuanshou's resolution greatly impressed the emperor. Later, Shunzhi made offerings to the monk and in 1659 ordered the transmission of full precepts to 750 monks led by him [13, p. 120-125]. Obviously, Shunzhi realized that he was dealing with a great Vinaya master.

During the Kangxi reign, Guangji monastery was among the temples where yearly longevity prayers were held for the emperor [4, p. 177]. Kangxi himself visited it in 1681, 1694 and 1695 [13, p. 143, 155, 156-157]. In the winter of 1681, the Great Compassion Altar (Dabei tan 大悲壇) was completed. At that time the southern regions were appeased, and the monastery held a "Sanctuary blessing the country and enriching the people“ (zhu guo yumin daochang 祝國裕民道塲) for 49 days and nights with the participation of Prince Kang 康親王. Also, Great Compassion Repentance (dabei chan 大悲懺) was practiced for 21 days [13, p. 154]. The use of such term as "altar" suggests the esoteric nature of the relevant rituals.

On November 19, 1694, as well as on May 13, 1695, the emperor visited the monastery, exploring the phenomenon of an unusual "brass tree" (tongshu 桐樹) in front of the abbots quarters. In the course of these years, the emperor and the heir apparent granted a number of valuable items to the monastery [13, p. 156158]. Kangxi's 1699 stela notes the presence of the library and ordination platform and directly links the monastery with Vinaya practice: "The root of his (the abbot's) teaching is benefiting living beings, and the activity is observance of precepts and discipline" [13, p. 47-48]. It was in the 1695 dialogue under the "brass tree" that the emperor clearly demonstrated the assumption that the monastery belonged to Vinaya lineage. However, he was informed that this was not the case anymore. The abbot Tianfu Zhanyou 天孚湛祐
(1642-1695) replied that he was a dharma grandson of Tiantong Muyun 天童牧雲 $(1599-1671)^{\mathrm{b}}$ and obtained dharma from Tianshu Xingzhi 天樹行植 (1633-1680) of Helin monastery 鶴林寺 in Jingkou 京口 [13, p. 157]. Here the account of developments in Guangji monastery provided by its gazetteer ends, as it was published in 1702, which leaves us uninformed about the faring of the monastery during later Kangxi and Yongzheng periods.

\subsection{Tanzhe monastery}

Tanzhe monastery, located in the Western mountains of Beijing, was a relatively large temple with several hundred monks. In her research paper on Tanzhe monastery, Susan Naquin quotes a 1725 stele claiming the number of "no less than three to five hundred" monks and prefers to stick to the 1740s observer who talked about "more than three hundred" [14, p. 200]. Another relevant piece of evidence is a dialog from the hagiography of the third abbot Dezhang Daolin 德彰道 林 (1661-1723, ab. 1702-1722) with Kangxi. The latter asked: "How many monks are there in Tanzhe [monastery]?" The master said: "Seven or eight hundred". The emperor asked: "Are food supplies enough?" And the master reported: "Without deficit but also with no surplus". After this exchange the emperor granted a purple robe to the abbot, which, as hagiography claims, was the sign of approval for his honesty [10, p. 0755a02-6]. Therefore, 700-800 may also be a number worth considering.

The enrooting of Vinaya school here took place when the Kangxi emperor ordered Zhenhuan Zhaofu 振寰照福 (1634-1699), who had been the abbot of Guangji monastery in Beijing since 1683, to move into Tanzhe monastery as its new abbot in 1686 [10, p. 0752b16-7]. Here it is possible to clarify Susan Naquin's doubt of whether Kangxi's 1686 visit to the monastery took place in spring. The monastery gazetteer places it in the autumn of 1686. Remarkably, Zhenhuan Zhaofu was appointed abbot in spring of that year according to his hagiography $[15$, p. 73,81$]$. This changes the logic of Kangxi proposed by Susan Naquin who claimed that the emperor first visited a picturesque site and only then became interested in its religious affairs. As can be seen from our evidence, Kangxi's involvement in the government of the monastery preceded his personal visit.

For two more generations, succession of abbotship here required petitioning to the emperor and gaining approval, as was in the cases of the second abbot in 1699 and third abbot in 1702 [10, p. 0754a03-4, b16-7]. However, there are no reports of such practice for the following generations of abbots ${ }^{c}$, with the next explicit petitioning taking place only in 1765 [10, p. 0817b05-7].

\footnotetext{
${ }^{\mathrm{b}}$ Tiantong Muyun, in turn, was a dharma heir of Miyun Yuanwu 密雲 圓悟 (1567-1642), a famous master of Chan (Linji) school.

${ }^{\mathrm{c}}$ No imperial involvement is mentioned for the succession of the fourth abbot in 1722 either in the genealogy or in the local gazetteer, as well as for the fifth abbot in 1728, the sixth abbot in 1736, and the seventh abbot in 1741, see [10, p. 0784b05, 0785b09-10, 0786b03-4; 11, p. 78].
} 
Notably, the disregard of petitioning took place with the transition from Kangxi to Yongzheng reign and resumed only in the later part of Qianlong period 乾隆 (17111799, r. 1736-1795). Besides the appointment of the abbot, Kangxi patronized Tanzhe monastery in a number of other ways. He visited the monastery in 1686 and 1702, sponsored restoration projects in 1686 and 1694, composed verses and granted gifts, including a purple robe $[10$, pp. $0752 b 18,0753 \mathrm{a} 08, \mathrm{~b} 16-8 ; 14$, p. 191]. A detailed list of offerings by Kangxi, empress and several princes can be found in [4, p. 173]. Also, he arranged medical treatment for an ill abbot in 1698 and summoned an abbot to tame tigers at his private zoo [10, p. 0753a03-4; 11, p. 76].

Apparently, during Kangxi reign Tanzhe monastery was solidly positioned within the scope of the emperor's heed. However, the question remains to what extent it was perceived as a Vinaya site. Here the result of Susan Naquin's meticulous research on the history of this monastery during Ming and Qing can provide valuable clues. She mentions "great ordination ceremonies", and clearly shows an ordination platform on a map [14, p. 186]. However, this altar was erected by the Zhengtong emperor of Ming and is not listed among the main contributions of Kangxi's construction [14, p. 188]. By contrast, Susan Naquin emphasized the introduction of Tantric components to the monastery, as Kangxi granted a number of Tibetan Buddhism paintings and also constructed Shurangama altar (Lengyan tan 楞嚴壇), which was extremely popular for esoteric ceremonies sponsored by lay devotees [14, p. 192, 195]. Also, in Chinese scholarship it was suggested that Kanxi's engagement with Tanzhe temple might be explained by the fact that this was the inevitable place on the road for touring Mt Wutai [4, p. 285], while supporting Tibetan Buddhism on Mt Wutai was an important tool of managing Mongolian and Tibetan subjects of the empire ${ }^{\mathrm{d}}$.

Apart from that, the monastery housed a set of the Buddhist canon granted by the Zhengtong emperor, and comprised external religious components such as folk beliefs in snakes that could be prayed to for rain [14, p. 187-8]. Moreover, various guides compiled either for public dissemination or for private use by the imperial court presented Tanzhe monastery more like a tourist site with spectacular vistas and historical relics, neglecting the devotional value of the place along with its clerical community [14, p. 192, 202]. In a nutshell, Susan Naquin's results mostly depict a multifaceted picture of Tanzhe monastery, on which the Vinaya elements virtually fade away. However, we can discover from the sources that Kangxi was aware that the monastery conducted activities typically deemed as the domain of Vinaya masters, i.e. ordination ceremonies. To be more precise, he mentions ordination altar in his 1702 verse [10, p. 0753a13-4]. Nirvana

Majestic Buddhist images [helping] investigation of

\footnotetext{
${ }^{d}$ At the same time, Susan Naquin notes that the monastery was 'on the road to nowhere, resolutely out of the way' [14, p. 184].
}

All stay on the mountain because of great dream.

If the bright mirror is not taken for the words of stand, than smile and point at true plan together with ordination altar.

法像儼然參涅槃 皆因大夢住山間

若非明鏡當臺語 笑指眞圖併戒壇

Still, along with pointing at ordinations, if read carefully, this verse reveals Chan rather than Vinaya pathos. "Investigate Nirvana" uses the verb can 參 typically denoting Chan meditation practices. "Bright mirror" and "stand" clearly refer to the competing verses of Shenxiu 神秀 and Huineng 慧能 from the Platform Sutra of the Sixth Patriarch (Liuzu tanjing 六祖壇經), a fundamental Chan Buddhist scripture, while "smile" (xiao 笑) might be linked to the description of how Buddha Shakyamuni started the supposed transmission of ineffable truth to Kashyapa by smiling silently with a flower in his hand, this also being an integral part of Chan narrative. Finally, the "pointing" ( $z h i$ 指) in the verse may be drawn from to Chan trope that verbal explanations leading to enlightenment are like a finger pointing at the moon, but not the moon itself.

The link between the monastery and Chan in Kangxi's eyes becomes even clearer from the name he bestowed on the site. Susan Naquin informs us that Kangxi renamed the place as "Tanzhe Mountain CloudPeak Temple” (Tanzheshan Xiuyunsi 潭柘岫雲寺) [14, p. 191], which is not quite accurate. In fact, the monastery gazetteer notes in several places that the new name plaque granted in 1692 read "Imperially built Tanzhe Mountain Cloud-Peak Chan Temple" (Chijian Tanzhe-shan Xiuyun Chansi 勅建潭柘山岫雲禪寺, italics are ours) [15, p. 22, 43]. Thus, even though Tanzhe monastery was obviously a hybrid Buddhist site with a mixture of Tantric, Vinaya, doctrinal, and folk elements, it did not hamper Kangxi from perceiving and positioning it as a predominantly Chan monastery.

As compared with Kangxi's huge involvement, Yongzheng is barely present on the pages of the monastery gazetteer. A very faint interaction can be found in the hagiography of the eighth abbot Jingguan Yuanrui 靜觀圓瑞 (1706-1781/2, ab. 1765-1781/2), who was summoned to participate in the preparation of the imperial edition of Buddhist canon initiated by the Yongzheng emperor [15, p. 206]. However, it is not possible to determine whether Yongzheng has personally chosen him for the task.

\subsection{Monastery on Mt Baohua}

Along with Minzhong monastery, Mt Baohua was one of the places revived by Guxin Ruxin's direct disciples, this time by Sanmei Jiguang 三昧寂光 (1580-1645). At the time of his arrival, the main monastery on the mountain was called Longchang 隆昌寺 (“Abundance and Prosperity"). The place fell within the range of attention of Qing emperors later than the capital monasteries discussed above. The link with the emperor Kangxi was established during his inspections to the southern regions of the country. He visited the monastery first in 1703, 
granting to the main temple of the mountain a plaque with the new name “Huiju” 慧居寺 (“Monastery where Wisdom abides"), as well as a Heart sutra and a Diamond sutra. In 1707, the emperor returned, now interacting more extensively with the place. He wrote four characters “Lianjie Yunxian” 蓮界雲香 (“Cloudy incense of lotus realm") for the Brass temple, four characters “Jingchi fanjie” 精持梵戒 (“Precise upholding of pure precepts") for the ordination platform, as well as three characters "Yongxianglin" 湧 香林 (“Grove of emerging incense") for the abbot's quarters. The emperor stayed in the monastery for one night and the abbot Songyin Zhenyi 松隱真義 (16601709, ab. 1700-1709) crossed Yangtze River to see the emperor off when the latter returned to the north. On this occasion, the emperor also granted other precious objects [10, p. 0756a06-17].

The next abbot Minyuan Changsong 閔緣常松 (1664-1718) was invited in the spring of 1713 by eunuchs and merchants from Guangling 廣陵 to the capital to conduct great festivities for the emperor's anniversary. The emperor visited the event and in the course of the conversation inquired whether there are monk poets on Mt Baohua, to which Minyuan Changsong noted: "The daily activity of Vinaya school is venerating and chanting, and there is no time to pay attention to elegance". Kangxi answered approvingly: "It is probably for this reason that the order of Vinaya can encompass the whole world". Thereafter, Kangxi granted imperial meals for the participating monks every day without cessation. Close to the end of the ceremonies he granted purple robe and several jade objects to the abbot and ordered him to return to the mountains in order to "eternally pacify Qianhua to accomplish the enormous deed of Great Peace" [10, p. 0788a15-b09]. This dialogue clearly informed Kangxi that Minyuan Changsong and the whole Mt Baohua belonged to Vinaya school and, even more explicitly, to its Qianhua lineage.

The short term of the next abbot Zhenhui Shiyong 珍 輝實[王*永] (1676-1722) that lasted from 1718 to 1722 was not marked with direct contacts with the emperor. However, each year longevity festivities were held at Mt Baohua to celebrate the emperor's birthday. Local officials attended under the lead of general-governor, providing food for monks and discussing key matters of Vinaya with the abbot [10, p. 0822b13]. Thus, at the local level Mt Baohua and more specifically its abbot continued to be known as the repository of Vinaya expertise. In the early years of Fuju's abbotship, in 1724, the Yongzheng emperor prescribed that provision of salt to Mt Baohua on the public expense be included into official register $[16$, p. 354]. So, the place was recognized as a worthy Buddhist site on imperial level.

Finally, Fuju completed a preliminary version of the genealogy of Vinaya school in early 1733, which is known from the preface by a former official Jing Kaoxiang 景考祥 (d.u., jinshi 1708) dated 1733 [9, part 4, p. 4-5]. It should be noted here that by means of composing the genealogy Fuju in fact voiced out the longstanding tradition of underscoring the importance of lineage at Mt Baohua. Ever since the first Vinaya abbot Sanmei Jiguang, the transmission of abbotship was a highly ritualized event including the handover of sacred items (robe, alms bowl and/or precepts book), according to stele inscriptions for its second, third and fourth abbots [16, p. 295, 305, 313].

By contrast, the other large capital monasteries analyzed in this paper lacked this kind of pronounced genealogy in Yongzheng's time. Firstly, Vinaya lineage in Guangji monastery ceased with the late seventeenth century abbot Tianfu Zhanyou, who associated himself with the Linji Chan school. Secondly, Minzhong monastery in Beijing had never strived to voice out a coherent master-student relationship between its abbot, which led to the claim in 1765 Genealogy of the Lamp of Vinaya School that even at that time it was not possible to determine to which dharma lineages its abbots belonged [10, p. 0880b10-12]. Thirdly, Genealogy of the Lamp of Vinaya School presents the abbots of Tanzhe monastery as the heirs belonging to the genealogical lineage ascending to the late sixteenth century Vinaya reviver Ruxin. Yet, this proclamation was made as late as 1765 , while a careful reading of hagiographies of abbots in the 1739 gazetteer of the monastery shows that no attempt was made to trace its origins before the late seventeenth century abbot Zhenhuan Zhaofu. Obviously, even in the end of 1730s Tanzhe leadership was not sensitive to genealogical concerns and felt no need of narrating their story in terms of lineage-fashioned succession. Thus, despite the proximity and prominence of the aforementioned Beijing monasteries to the eye of the emperor, all of them had a shortcoming as compared to Mt Baohua. Even though they conducted ordination ceremonies and often titled their abbots as Vinaya masters, they either lacked a genealogical link to the revived Vinaya school or failed to voiced it in the right time to be noticed by the Yongzheng emperor.

\section{Conclusions}

From the very beginning, this paper followed the Japanese scholar Hasebe Yūkei in identifying Beijing monasteries that could have competed for imperial favour with Mt Baohua, based on a genealogy of the Vinaya school compiled in the eighteenth century. However, the overall picture that this research revealed is far more complex. All of the three most prominent Beijing monasteries under consideration - Tanzhe, Guangji, and Minzhong - to a greater or lesser extent showed aberration from purely Vinaya specialization. At a certain point during the Kangxi reign, the abbots of both Guangji and Minzhong felt stronger affinity and interest in the Chan tradition rather than in the matters of Vinaya. Apart from the fact that these monasteries were in fact hybrid in their functionality, this multifaceted character was known at least to the Kangxi emperor and even strengthened by him. Still, this diverse profile of the monasteries in Beijing did not hinder the emperors from recognizing their Vinaya affiliations. According to 
the sources, at least to Kangxi, the existence of ordination platforms there was well known.

These findings, in turn, invalidate two assumptions about what factors might have made capital monasteries "inferior" to Mt Baohua in Yongzheng's eyes. Firstly, there is no doubt that the very existence of these places as centres of Vinaya study and practice was known to the emperors. So, it was not the case that Mt Baohua was a highly-reputed Vinaya site while Beijing lacked such prominent places. Secondly, the degree of imperial interaction with the monasteries in the capital was far greater than with their southern counterpart both in terms of frequency and in terms of depth of involvement.

At this point we propose that in search of a key element of Mt Baohua's success it is much more fruitful to turn to the factor of existence and articulation of a lineage. This was an alternating quality over time. An abbot of Guangji monastery switched his affiliation to Chan in the late sixteenth century. Tanzhe monastery possessed an uninterrupted Vinaya lineage, but made it known to public only in 1765. Minzhong monastery was the most specialized Vinaya venue as compared to other capital sites, but it never boasted the existence of a Vinaya lineage to the outside world. By contrast, Mt Baohua had a long history of cultivating the notion of lineage within the school, and Fuju advertised it in a 1733 genealogy, which was prefaced by a high-standing Beijing official right on the eve of Yongzheng's decision to summon Fuju to the capital ${ }^{\mathrm{e}}$.

These findings not only cast new light on how the socalled Vinaya monasteries functioned, were perceived and presented themselves, but also on the way of interaction between Qing emperors and Buddhist clerics. More specifically, they prompt us to reconsider Hasebe Yūkei's argument that it was the role in conducting ordinations that the Yongzheng emperor considered at the heart of his attempt of curbing the Chan school by elevating the Vinaya school. It appears that regular ordinations were already held at Yongzheng's time in such capital monasteries as Tanzhe and Minzhong. In particular, Minzhong was the most specialized Vinaya monastery at that time, and it was evidently not by chance that Yongzheng chose it as the venue for the precepts transmission by Fuju. Rather, it should be concluded that Yongzheng wished to promote the standing of southern Mt Baohua lineage of Vinaya because at that time it could articulate a genealogically organized school structure with a potential to challenge the dominance of Chan, pulling over a certain number of monks from potential Chan affiliation.

\section{References}

1. B. j. ter Haar. The People and the Dao: New Studies in Chinese Religions in Honour of Daniel L. Overmyer, 435-77 (Sankt Augustin-Nettetal, Routledge, 2009)

\footnotetext{
${ }^{\mathrm{e}}$ The temporal proximity of these two events and the corresponding possibility of causal connection was already noted in [17].
}

2. J. Wu. Enlightenment in dispute: the reinvention of Chan Buddhism in seventeenth-century China (New York, Oxford University Press, 2008)

3. D. Long. Spreading Buddha's Word in East Asia: The Formation and Transformation of the Chinese Buddhist Canon, 219-24 (New York, Columbia University Press, 2016)

4. H. Lai, Y. Zeng. Wei jun nan - Yongzheng qiren, qishi ji qi shidai lunwenji, 169-88 (Taibei, Gugong bowuguan, 2010).

5. J. Wang. Zhongguo lüzong tongshi (Nanjing, Fenghuang, 2006)

6. Y. Hasebe. Journal of the Institute for Zen Studies 21, 89-98 (1993)

7. Y. Hasebe. Journal of the Institute for Zen Studies 23, 113-39 (1995).

8. Shengkai. Shijie zongjiao yanjiu 5, 35-42 (2014).

9. Fuju. Nanshan zongtong (Beijing, Zongjiao wenhua, 2011).

10. Yuanliang. Lüzong dengpu. M. of acc.: http://tripitaka.cbeta.org/B22n0118_001 (accessed: 30.09.2020)

11. Sh. Wang, W. Huang. Fayuan sizhi gao. M. of acc.: http://buddhistinformatics.dila.edu.tw/fosizhi/ui.htm 1?book=y005 (accessed: 30.09.2020)

12. Fayuansi zhi (Beijing, Wuzhou chuanbo, 2009).

13. Chijian Hongci Guangjisi xinzhi. M. of acc.: http://buddhistinformatics.dila.edu.tw/fosizhi/\#g048 (accessed: 30.09.2020)

14. S. Naquin. Cahiers d'Extrême-Asie Année 10, 183211 (1998).

15. Tanzheshan Xiuyunsi zhi. M. of acc.: http://buddhistinformatics.dila.edu.tw/fosizhi/ui.htm 1?book=g047 (accessed: 30.09 .2020 )

16. Baohua shanzhi. M. of acc.: http://buddhistinformatics.dila.edu.tw/fosizhi/ui.htm 1?book=g041 (accessed: 30.09.2020)

17. M. Lepneva. History magazine - research 3, 93-105 (2019). 